\section{Adaptation to lactose in lactose malabsorbers - importance of the intestinal microflora}

\author{
By Rangne Fondén
}

\begin{abstract}
At high intakes most lactose in lactose malabsorbers will be fermented by the intestinal microflora to hydrogen and other fermentation products, as are all other low-molecular, nonabsorbable, fermentable carbohydrates. By adaptation higher intakes of lactose could be tolerated partly due to a lower net formation of hydrogen. This shift in fermentation is at least partly caused by a change in the activities of the intestinal microflora.

Keywords: Adaptation, hydrogen production, lactose malabsorbtion, intestinal microflora
\end{abstract}

\section{Lactose as a substrate to the intestinal microflora}

Lactose malabsorbers will only digest minor amounts of lactose in the small intestine due to low lactase activity. At higher intakes most of the lactose will be fermented by the intestinal microflora. Lactic acid bacteria, and other bacteria able to ferment lactose, will perform the first step in the fermentation chain. They will form intermediate substances like galactose, lactic and acetic acid with only a minor amount of hydrogen produced. Some of the intermediate substances will be absorbed by the human intestine, some will be fermented to organic acids and other compounds such as hydrogen, methane and sulphite $(1,2)$. When the formation of gaseous compounds is higher than the absorption through the intestine, the surplus could cause symptoms characteristic of lactose intolerance, such as flatulence, diarrhoea and abdominal pain. The symptoms are identical to those caused by other low-molecular, non-absorbable, fermentable carbohydrates as exemplified by lactulose, fructooligosacharides and sorbitol partly used as sugar substitutes $(3,4)$.

\section{Adaptation to lactose}

Adaptation to lactose has been investigated and demonstrated in at least four different studies (5-8). Healthy lactose-maldigesters of different ages have been given lactose for 10,14, 21 and at most 88 days. Lactose intake in the different experiments was either constant at about $30 \mathrm{~g}$ daily or increased from 5-20 g at the beginning up to 8-65 $\mathrm{g}$ daily at the end of the studies. Hydrogen production decreased during the adaptation periods as measured both by breath test and by fewer symptoms of flatulence. Likewise the activity of faecal $\beta$-galactosidase increased during adaptation. Thereafter an improved capacity to ferment lactose without gastrointestinal symptoms was proven as the severity of the symptoms caused by lactose challenge was reduced in comparison to those reported before adaptation. In control groups given dextrose or sucrose as a placebo, no impact either on hydrogen production or on faecal $\beta$-galactosidase was documented after lactose provocation. However, results from one of the investigations indicated that factors other than adaptation of the microflora might be of importance. Symptoms after lactose intake in both the experimental and the placebo group were reduced at the end of the intervention period, indicating that the strength of the symptoms might be partly due to individual expectations (8).

Rangne Fondén, senior scientist, Arla Foods, SE-105 46 Stockholm, Sweden. E-mail:Rangne.Fonden@arlafoods.com

The article is based on a lecture presented at the meeting Lactose intolerance revisited, Febuary 1-2, 2001, Stockholm, Sweden.
Evidence of adaptation of the intestinal microflora

The activities of the faecal microflora are changed when it is exposed to lactosefor several days, as evidenced by a reduced excretion of hydrogen by breath and a lower incidence of flatulence (5-8). A similar impact on lactose fermentation was noticed after adaptation to $20 \mathrm{~g}$ lactulose daily (9). In one of the studies faecal $\mathrm{pH}$ was also followed. It decreased during the adaptation indicating an increased capacity of the gastrointestinal microflora to ferment the new carbon source (7).

The impact on the hydrogen excretion might be due either to on a lowered production or to an increased consumption of hydrogen by the intestinal microflora. Hydrogen could be used to form methane or acetic acid or to reduce sulphate (2). To estimate the relative importance of hydrogen production and of consumption, faecal slurries were incubated with lactose (10). The faecal samples were taken after a 10-day period of lactose/ dextrose adaptation. Hydrogen production was three times lower from slurries after lactose adaptation in comparison to dextrose. Hydrogen consumption was estimated by comparing data from slurries with or without inhibitors to known consumption reactions. Data indicated that consumption was of minor importance (10).

The net reduced hydrogen formation noticed after an adaptation to lactose could have several different explanations. A prolonged oroceacal transport time will result in an increased hydrolysis of lactose by remaining lactase and an increased absorption of galactose, lactic acid and acetic acid formed by homofermentative lactic acid bacteria and bifidobacteria. Although not proved by ex-vivo studies, hydrogen consumption might still be of importance. Studies indicate that acetogenesis, formation of acetic acid from hydrogen and carbon dioxide, might be stimulated by a low $\mathrm{pH}$ produced by fermentation of the lactose $(2,12)$.

\section{Conclusions}

Adaptation to lactose allows lactose maldigesters to consume milk and other dairy products without symptoms caused by the formation of hydrogen. Further studies are needed to evaluate the different aspects of the adaptation process including the importance of the gastrointestinal microflora.

\section{REFERENCES}

1. Wolin MJ, Miller T: Carbohydrate fermentation. In: Hentges DJ ed. Human intestinal microflora in health and diseases, Academic Press, London 1983:1447-65.

2. Gibson GR, Cummings JH, Macfarlane GT, Allison C, Segal I, Vorster HH, Walker AR: Alternative pathways for hydrogen disposal during fermentation in the human colon. Gut 1990;31:679-83.

3. Hyams JS: Sorbitol intolerance: an unappreciated cause of functional gastrointestinal complaints. Gastroenterology 1983;84:30-3.

4. Stone-Dorshow T, Levitt MD: Gaseous response to ingestion of a poorly absorbed fructo-oligosaccharide sweetener. Am J Clin Nutr 1987;46:61-5.

5. Johnson AO, Semenya JG, Buchowski MS, Enwonwu CO, Scrimshaw NS Adaptation of lactose maldigesters to continued milk intakes. Am J Clin Nutr 1993;58:879-81.

6. Hertzler SR, Saviano DA: Colonic adaptation to daily lactose feeding in lactose maldigesters reduces lactose intolerance. Am J Clin Nutr 1996;64 232-6.

7. Briet F, Pouchart P, Marteau P, Arrigoni E, Rambaud JC: Improved clinical tolerance to lactose ingestion in subjects with lactose intolerance: a placebo effect? Gut 1997;41:715-6.

8. Pribila BA, Hertzler SR, Martin BR, Weaver CM, Saviano DA: Improved lactose digestion and intolerance among African-American adolescent girls fed a dairy-rich diet. J Am Diet Assoc 2000;100:524-8.

9. Szilagyi A, Rivard J, Fokeeff K: Improved parameters of lactose maldigestion using lactulose. Dig Dis Sci 2001;46:1509-19.

10. Hertzler SR, Saviano DA, Levitt MD: Fecal hydrogen production and consumption measurements. Response to daily lactose ingestion by lactose maldigesters. Dig Dis Sci 1998;43:39-40.

11. Peuhkuri K, Vapaatalo H, Nevala R, Korpela R. Influence of the pharmacological modification of gastric emptying on lactose digestion and gastrointestinal symptoms. Aliment Pharmacol Ther 1999;13:81-6.

12. Vogelsang H, Ferenci P, Frotz S, Meryn S, Gangl A: Acidic colonic microclimate-possible reason for false negative hydrogen breath tests. Gut 1988;29:21-6. 